\title{
Cinnamomum Oliveri F. M. Bailey Leaf Solvent Extractions Inhibit the Growth of a Panel of Pathogenic Bacteria
}

Getmore Rumbudzai Chikowe ${ }^{1}$, Lindiwe Nomathemba Mpala², Ian Edwin Cock ${ }^{\text {* }}$

'School of Natural Sciences, Griffith University, 170 Kessels Rd, Nathan, Brisbane, Queensland 4111, AUSTRALIA

2Environmental Futures Research Institute, Griffith University, 170 Kessels Rd, Nathan, Brisbane, Queensland 4111, AUSTRALIA

\begin{abstract}
Introduction: Cinnamomum oliveri F. M. Bailey is a rain forest tree native to Australia. Decoctions, infusions and essential oils produced from the leaves were used traditionally to treat a variety of bacterial diseases. Despite this, $C$. oliveri leaf extractions have not been rigorously examined for antibacterial properties against many pathogens. Methods: The antimicrobial activity of $C$. oliveri leaf extractions was investigated by disc diffusion and growth time course assays against a panel of pathogenic bacteria. The growth inhibitory activity was quantified by MIC determination. Toxicity was determined using the Artemia franciscana nauplii bioassay. Results: $C$. oliveri leaf solvent extractions inhibited the growth of a wide range of bacterial species. Growth of both gram positive and gram negative bacteria was inhibited by the $C$. oliveri leaf extracts to approximately the same extent. The methanolic extracts were generally most potent growth inhibitors. The methanolic, aqueous and ethyl acetate $C$. oliveri leaf extracts were particularly potent inhibitors of $P$. mirabilis growth, with $\mathrm{MIC}$ values as low as $127 \mathrm{\mu g} / \mathrm{mL}$ (methanolic extract). A. coli, K. pneumoniae and $B$. cereus were also particularly susceptible to the methanolic, aqueous and ethyl acetate extracts, with MIC values generally substantially $<1000 \mu \mathrm{g} /$ $\mathrm{mL}$. The antibacterial activity of the methanolic $C$. oliveri leaf extract was
\end{abstract}

further investigated by growth time course assays which showed significant growth inhibition in cultures of $E$. coli, $K$. pneumoniae and P. mirabilis within $1 \mathrm{~h}$ of exposure. All extracts were determined to be nontoxic in the Artemia franciscana nauplii bioassay, indicating their safety for internal use as well as for topical uses. Conclusions: The lack of toxicity of the $C$. oliveri leaf extracts and their growth inhibitory bioactivity against a panel of pathogenic bacteria partially validate the traditional usage of these species to treat bacterial diseases and indicate their potential in the development of antiseptic agents.

Key words: Lauraceae, Oliver's Sassafras, Black Sassafras, Camphorwood, Cinnamon wood, Australian Plants, Antibacterial Activity, Medicinal Plants.

Correspondence:

Ian Edwin Cock,

School of Natural Sciences, Griffith University, 170, Kessels Rd, Nathan, Brisbane, Queensland 4111, Australia

Tel : +61 737357637

Fax: +61737355282

E-mail: I.Cock@griffith.edu.au (I. E. Cock)

DOI : $10.5530 /$ pc.2017.2.11

\section{INTRODUCTION}

Plants produce a wide variety of compounds, which in addition to giving them characteristic pigment, odour and flavour characteristics, may also have antimicrobial properties. ${ }^{1}$ For thousands of years, traditional plant derived medicines have been used in most parts of the world and their use in fighting microbial disease is becoming the focus of intense study., ${ }^{2,3}$ Whilst much of the research into traditional medicinal plant use has focused on Asian, ${ }^{4}$ African ${ }^{5}$ and South American ${ }^{6}$ plants, the therapeutic potential of the flora of Australia has been recognised for many thousands of years. The first Australians had well developed ethno-pharmacological systems and understood the therapeutic properties of a wide variety of aromatic Australian plants. ${ }^{7}$ Despite this, relatively few studies have rigorously examined the antibacterial activity of Australian native plants, although recently there has been increased study in this field.

Cinnamomum oliveri F.M.Bailey (family Lauraceae; commonly known as camphorwood, Oliver's sassafras, black sassafras and cinnamon wood) is a medium-large tree which is native to rainforest regions of north eastern Australia. The trees grow $25 \mathrm{~m}$ tall with buttressed trunks. The glossy green leaves (Figure 1a) are lanceolate with wavy margins and grow to 15 $\mathrm{cm}$ long by $4 \mathrm{~cm}$ wide. When broken, the leaves and twigs emit a sarsaparilla-like odour. White to cream flowers are produced in panicles approximately $6 \mathrm{~mm}$ long (Figure 1b). The flowers develop into small aromatic drupes to approximately $12 \mathrm{~mm}$ (Figure 1c) which ripen to a glossy black colour. Interestingly, Australian Aborigines used bark decoctions to treat diarrhoea and dysentery and several other bacterial diseases. ${ }^{7}$ Despite this, antibacterial studies of Cinnamomum oliveri leaves are lacking.

Several interesting phytochemical components have been identified in C. oliveri leaves. In particular, several terpenoids components have been isolated from C. oliveri leaf and bark and identified as camphor (Figure 1d), safrole (Figure 1e), eugenol (Figure 1f), methyl eugenol (Figure 1g) and cinnamic aldehyde (Figure 1h). Growth inhibitory properties have previously been reported for many of these terpenoids against several bacteria. ${ }^{8}$ Despite these promising studies, examination of the antibacterial properties and phytochemistry of the leaves from C. oliveri is lacking. The current report was undertaken to screen C. olioveri leaf extracts for growth inhibitory properties against a panel of pathogenic bacteria.
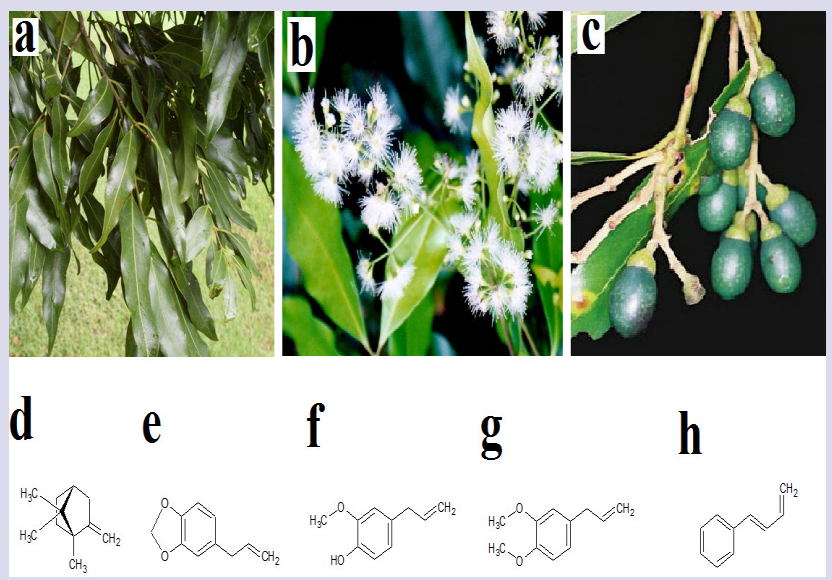

Figure 1: C. oliveri (a) leaves, (b) flower and (c) fruit, as well as the chemical structures of (d) camphor, (e) safrole, (f) eugenol, (g) methyl eugenol, (h) cinnamic aldehyde. 


\section{MATERIALS AND METHODS}

\section{Plant collection and extraction}

Cinnamomum oliveri F.M.Bailey leaves were obtained from and identified by Philip Cameron, senior botanic officer, Mt Cootha Botanical Gardens, Brisbane, Australia. Leaf samples were dried in a Sunbeam food dehydrator and stored at $-30{ }^{\circ} \mathrm{C}$. Prior to use, the leaves were freshly ground to a coarse powder and $1 \mathrm{~g}$ quantities were weighed into separate tubes. A volume of $50 \mathrm{~mL}$ methanol, sterile deionised water, ethyl acetate, chloroform or hexane was added to individual tubes and extracted for $24 \mathrm{~h}$ at $4{ }^{\circ} \mathrm{C}$ with gentle shaking. All solvents were obtained from Ajax, Australia and were AR grade. The extracts were filtered through filter paper (Whatman No. 54) under vacuum, followed by drying by rotary evaporation in an Eppendorf concentrator 5301. The resultant pellets were dissolved in $10 \mathrm{~mL}$ sterile deionised water (containing $1 \% \mathrm{DMSO}$ ). The extracts were passed through $0.22 \mu \mathrm{m}$ filter (Sarstedt) and stored at $4{ }^{\circ} \mathrm{C}$ until use.

\section{Qualitative phytochemical studies}

Phytochemical analysis of the C. oliveri leaf extracts for the presence of saponins, phenolic compounds, flavonoids, phytosteroids, triterpenoids, cardiac glycosides, anthraquinones, tannins and alkaloids was conducted by previously described assays. ${ }^{9-11}$

\section{Antibacterial screening}

\section{Test microorganisms}

All media was supplied by Oxoid Ltd., Australia. Clinical isolate microbial strains of Aeromonas hydrophilia, Alcaligenes feacalis, Bacillus cereus, Citrobacter freundii, Escherichia coli, Klebsiella pneumoniae, Proteus mirabilis, Pseudomonas fluorescens, Salmonella newport, Serratia marcescens, Shigella sonneii, Staphylococcus aureus, Staphylococcus epidermidis and Streptococcus pyonenes were obtained from Ms Michelle Mendell and Ms Jane Gifkins, Griffith University. All stock cultures were subcultured and maintained in nutrient broth at $4{ }^{\circ} \mathrm{C}$.

\section{Evaluation of antimicrobial activity}

Antimicrobial activity of all plant extracts was determined using a modified disc diffusion assay. ${ }^{12-14}$ Briefly, $100 \mu \mathrm{L}$ of each bacterial culture was grown in $10 \mathrm{~mL}$ of fresh nutrient broth until they reached a count of $\sim 10^{8}$ cells $/ \mathrm{mL}$. A volume of $100 \mu \mathrm{L}$ of the bacterial suspension was spread onto nutrient agar plates and extracts were tested for antibacterial activity using $5 \mathrm{~mm}$ sterilised filter paper discs. Discs were infused with $10 \mu \mathrm{L}$ of the plant extracts, allowed to dry and placed onto the inoculated plates. The plates were allowed to stand at $4{ }^{\circ} \mathrm{C}$ for $2 \mathrm{~h}$ before incubation at $30{ }^{\circ} \mathrm{C}$ for $24 \mathrm{~h}$. The diameters of the inhibition zones were measured to the closest whole millimetre. Each assay was performed in at least triplicate. Mean values ( \pm SEM) are reported in this study. Standard discs of ampicillin $(10 \mu \mathrm{g})$ were obtained from Oxoid, Australia and were used as positive controls to compare antibacterial activity. Filter discs infused with $10 \mu \mathrm{L}$ of distilled water were used as a negative control.

\section{Minimum inhibitory concentration (MIC) determination}

The minimum inhibitory concentration (MIC) of each extract against susceptible bacteria was determined as previously described. ${ }^{15,16}$ Briefly, the $C$. oliveri extracts were diluted in deionised water and tested across a range of concentrations. Discs were infused with $10 \mu \mathrm{L}$ of the test dilutions, allowed to dry and placed onto inoculated plates. The assay was completed as outlined above and graphs of the zone of inhibition versus concentration were plotted for each extract. Linear regression was used to determine the MIC values of each extract.

\section{Bacterial growth time course assay}

Bacterial growth time course studies were performed as previously described. ${ }^{17,18}$ Briefly, $3 \mathrm{~mL}$ of the E. coli, K. pneumoniae and P. mirabilis bacterial cultures in nutrient broth were added individually to $27 \mathrm{~mL}$ nutrient broth containing $3 \mathrm{~mL}$ of $10 \mathrm{mg} / \mathrm{mL}$ methanolic plant extract to give a final concentration of $1000 \mu \mathrm{g} / \mathrm{mL}$ in the assay. The tubes were incubated at $30{ }^{\circ} \mathrm{C}$ with gentle shaking. The optical density was measured hourly at $550 \mathrm{~nm}$ for a $6 \mathrm{~h}$ incubation period. Control tubes were incubated under the same conditions but without the extract. All assays were performed in triplicate.

\section{Toxicity screening}

\section{Reference toxin for toxicity screening}

Potassium dichromate $\left(\mathrm{K}_{2} \mathrm{Cr}_{2} \mathrm{O}_{7}\right)$ (AR grade, Chem-Supply, Australia) was prepared as a $4 \mathrm{mg} / \mathrm{mL}$ solution in distilled water and was serially diluted in artificial seawater for use in the Artemia franciscana nauplii bioassay.

\section{Artemia franciscana nauplii toxicity screening}

Toxicity was tested using an adapted Artemia franciscana nauplii lethality assay. ${ }^{19-21}$ Briefly, $400 \mu \mathrm{L}$ of seawater containing approximately 46 (mean 46.3, $\mathrm{n}=75, \mathrm{SD} 11.6$ ) A. franciscana nauplii were added to wells of a 48 well plate and immediately used for bioassay. A volume of 400 $\mu \mathrm{L}$ of diluted plant extracts or the reference toxin were transferred to the wells and incubated at $25 \pm 1^{\circ} \mathrm{C}$ under artificial light (1000 Lux). A $400 \mu \mathrm{L}$ seawater negative control was run in triplicate for each plate. All treatments were performed in at least triplicate. The wells were checked at regular intervals and the number of dead counted. The nauplii were considered dead if no movement of the appendages was detected within 10 seconds. After $24 \mathrm{~h}$, all nauplii were sacrificed and counted to determine the total $\%$ mortality per well. The $\mathrm{LC}_{50}$ with $95 \%$ confidence limits for each treatment was determined using probit analysis.

\section{Statistical analysis}

Data are expressed as the mean \pm SEM of at least three independent experiments. One way ANOVA was used to calculate statistical significance between control and treated groups with a $P$ value $<0.01$ considered to be statistically significant.

\section{RESULTS}

\section{Liquid extraction yields and qualitative phytochemical screening}

Extraction of $1 \mathrm{~g}$ of dried and powdered C. oliveri leaves with solvents of varying polarity yielded dried extracts ranging from $53 \mathrm{mg}$ (ethyl acetate extract) to $164 \mathrm{mg}$ (chloroform extract) (Table 1). The aqueous $(145 \mathrm{mg})$ and methanolic extracts $(104 \mathrm{mg})$ also yielded relatively high levels of extracted materials. The dried extracts were resuspended in $10 \mathrm{~mL}$ of deionised water (containing 1\% DMSO), resulting in the extract concentrations shown in Table 1. Qualitative phytochemical studies showed that the high to mid polarity methanol, water and ethyl acetate solvents extracted the greatest diversity and highest levels of phytochemicals. These extracts contained high levels of water soluble phenolics and flavonoids, and low levels of triterpenoids. The aqueous and ethyl acetate extracts also contained low levels of alkaloids. Interestingly, despite extracting relatively large amounts of material, the chloroform and hexane extracts were devoid of all classes of phytochemicals screened. Due to their nonpolar nature, these extracts would be expected to contain high levels of lipids, hydrocarbons etc. As our qualitative phytochemical studies did not screen for these compounds, they were 


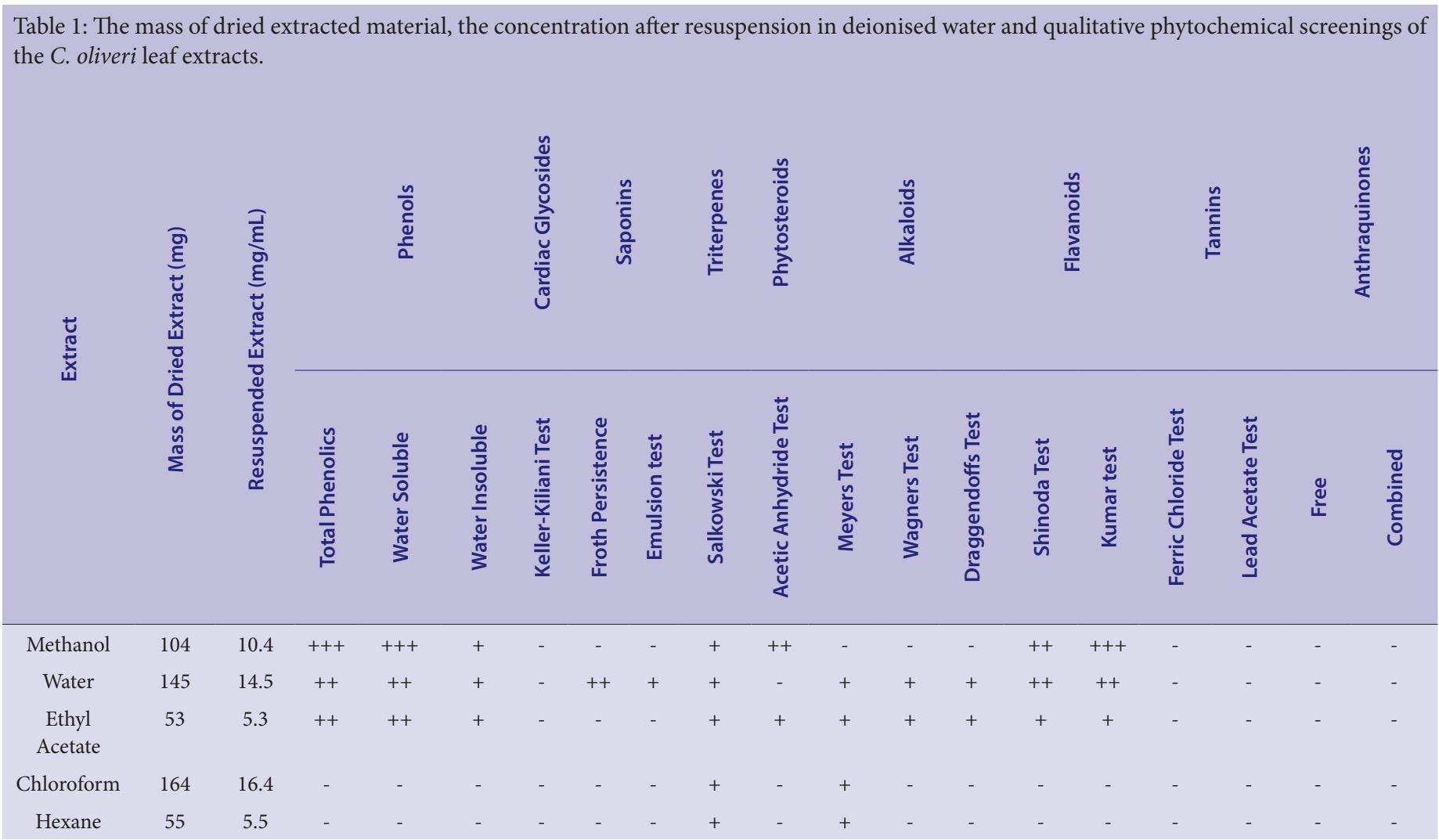

+++ indicates a large response; ++ indicates a moderate response; + indicates a minor response; - indicates no response in the assay.

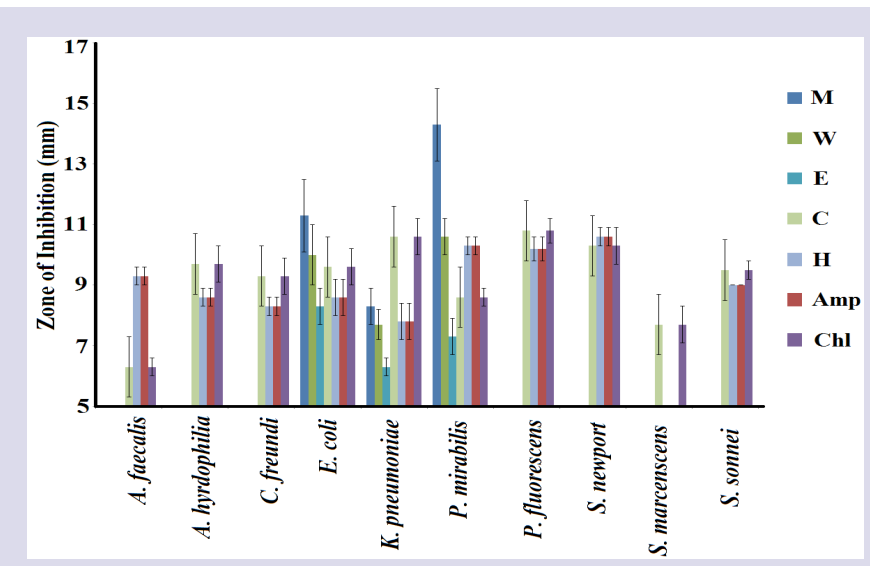

Figure 2: Growth inhibitory activity of $C$. oliveri leaf extracts against the gram negative bacterial species measured as zones of inhibition $(\mathrm{mm})$ \pm SEM. $M=$ methanolic extract; $W=$ aqueous extract; $E=$ ethyl acetate extract; $\mathrm{C}=$ chloroform extract; $\mathrm{H}=$ hexane extract; $\mathrm{Amp}=$ ampicillin (10 $\mu \mathrm{g})$ control; $\mathrm{Chl}=$ chloramphenicol $(2 \mu \mathrm{g})$ control. All determinations were in at least triplicate and the results are expressed as mean zones of inhibition $(\mathrm{mm}) \pm$ SEM.

not detected. Other techniques are required to further examine the nature of these nonpolar components.

\section{Antimicrobial activity}

To determine the growth inhibitory activity of the $C$. oliveri leaf extracts against the panel of pathogenic bacteria, aliquots $(10 \mu \mathrm{L})$ of each extract were screened in the disc diffusion assay. The C. oliveri leaf extracts were

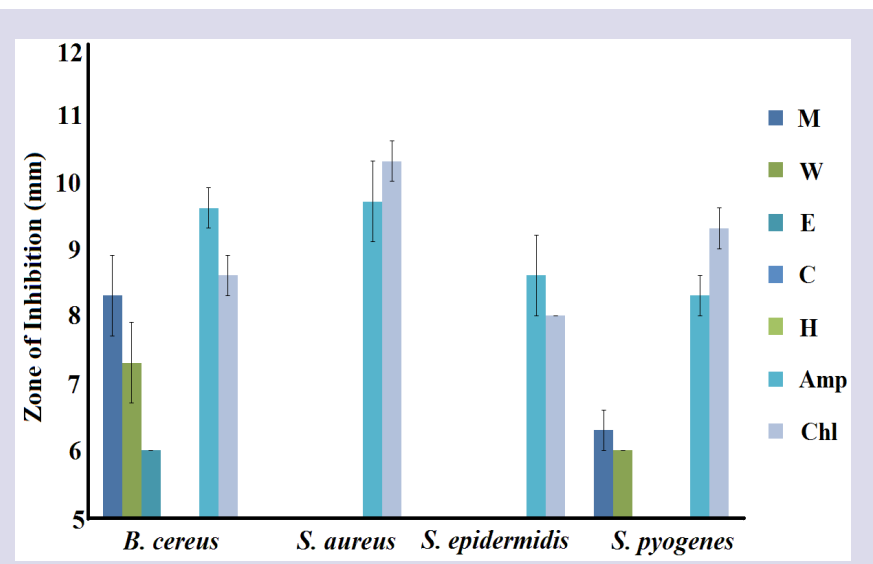

Figure 3: Growth inhibitory activity of $C$. oliveri leaf extracts against the gram positive bacterial species measured as zones of inhibition $(\mathrm{mm}) \pm$ SEM. $M$ = methanolic extract; $W=$ aqueous extract; $E=$ ethyl acetate extract; $\mathrm{C}=$ chloroform extract; $\mathrm{H}=$ hexane extract; $\mathrm{Amp}=$ ampicillin $(10$ $\mu \mathrm{g})$ control; $\mathrm{Chl}=$ chloramphenicol $(2 \mu \mathrm{g})$ control. All determinations were in at least triplicate and the results are expressed as mean zones of inhibition $(\mathrm{mm}) \pm$ SEM.

potent inhibitors of several gram negative bacterial species (Figure 2). Of the 10 gram negative bacterial strains tested, 3 (30\%) were inhibited by all C. oliveri leaf extracts. E. coli, K. pneumoniae and P. mirabilis were highly susceptible to the $C$. oliveri extracts. Indeed, the growth of these bacteria was inhibited by all of the C. oliveri extracts. The higher polarity methanolic and aqueous extracts were the most potent bacterial growth inhibitors against most susceptible bacterial species compared 
Table 2: Minimum bacterial growth inhibitory concentration $(\mu \mathrm{g} / \mathrm{mL})$ of the $C$. oliveri leaf extracts against susceptible bacterial species.

\begin{tabular}{|c|c|c|c|c|c|}
\hline \multirow[t]{2}{*}{ Bacterial species } & \multicolumn{5}{|c|}{ C. oliveri Extract } \\
\hline & Methanol & Water & Ethyl Acetate & Chloroform & Hexane \\
\hline \multicolumn{6}{|l|}{ Gram negative } \\
\hline A. faecalis & - & - & - & 2873 & 1467 \\
\hline A. hydrophilia & - & - & - & 2076 & 1650 \\
\hline C. freundi & - & - & - & 2250 & 1809 \\
\hline E. coli & 215 & 427 & 330 & 1255 & 1438 \\
\hline K.pneumoniae & 686 & 706 & 1286 & 1023 & 1562 \\
\hline P. mirabilis & 127 & 525 & 688 & 987 & 1066 \\
\hline P. fluroscens & - & - & - & 1738 & 1354 \\
\hline S. newport & - & - & - & 1924 & 1285 \\
\hline S. marcenscens & - & - & - & 4050 & - \\
\hline S. sonnei & - & - & - & 1436 & 1387 \\
\hline \multicolumn{6}{|l|}{ Gram positive } \\
\hline B. cereus & 613 & 984 & 1500 & - & - \\
\hline S. aureus & - & - & - & - & - \\
\hline S. epidermidis & - & - & - & - & - \\
\hline S. pyogenes & 1680 & 2263 & - & - & - \\
\hline
\end{tabular}

Numbers indicate the mean MIC values of triplicate determinations. - indicates no inhibition.

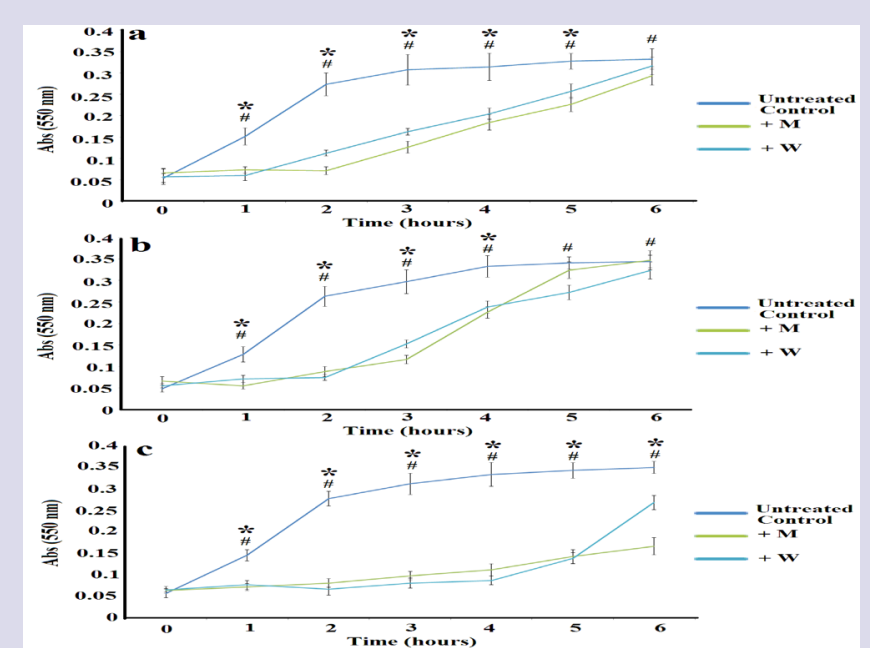

Figure 4: Bacterial growth curves for the methanolic and aqueous $C$. oliveri leaf extract against (a) E. coli, (b) K. pneumoniae and (c) P. mirabilis. All bioassays were performed in at least triplicate and are expressed as mean \pm SEM. ${ }^{*}=$ growth results in the presence of the methanolic extract that are significantly different to the untreated control growth $(p<0.01) ; \#=$ growth results in the presence of the aqueous extract that are significantly different to the untreated control growth $(p<0.01)$.

with the lower polarity extracts (as assessed by the sizes of the zones of inhibition). The methanolic C. oliveri extract strongly inhibited E. coli and $P$. mirabilis growth with $11.3 \pm 1.2 \mathrm{~mm}$ and $14.3 \pm 1.2 \mathrm{~mm}$ zones of inhibition respectively. The aqueous extract was similarly potent with 10 $\pm 1 \mathrm{~mm}$ and $10.6 \pm 0.6 \mathrm{~mm}$ zones of inhibition against $E$. coli and $P$. mirabilis respectively. This inhibition was particularly noteworthy compared to the inhibition by the ampicillin $(10 \mu \mathrm{g}$ : inhibition zones of $8.6 \pm 0.6$ $\mathrm{mm}$ and $10.3 \pm 0.3 \mathrm{~mm})$ and chloramphenicol controls $(2 \mu \mathrm{g}$ : inhibition

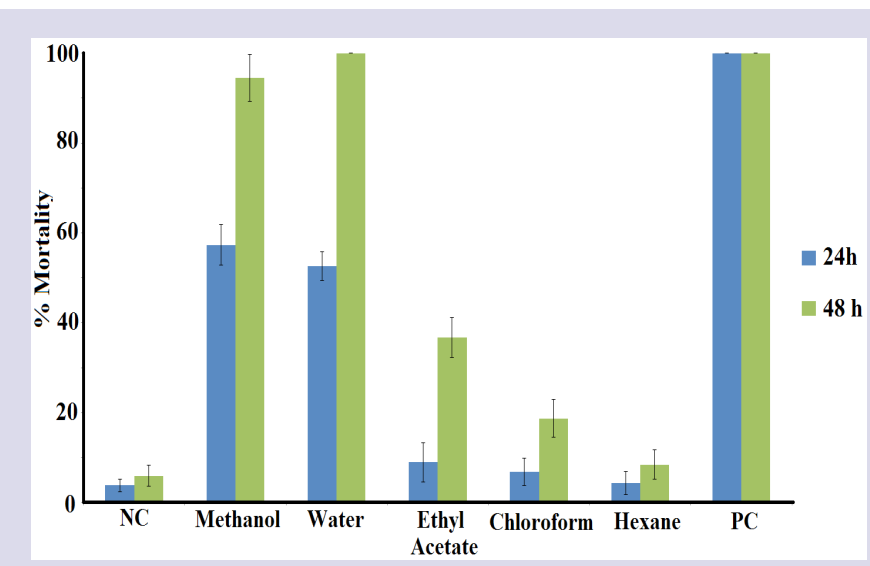

Figure 5: The lethality of the C. oliveri leaf extracts $(2000 \mu \mathrm{g} / \mathrm{mL})$, potassium dichromate $(1000 \mu \mathrm{g} / \mathrm{mL})$ and a seawater control. Blue bars represent the \% mortality following $24 \mathrm{~h}$ exposure to the extract/toxin. Green bars represent the \% mortality following $48 \mathrm{~h}$ exposure to the extract/ toxin. $\mathrm{NC}=$ negative (seawater) control; $\mathrm{PC}=$ positive control $(1000 \mu \mathrm{g} /$ $\mathrm{mL}$ potassium dichromate). All bioassays were performed in at least triplicate and are expressed as mean \pm SEM.

zones of $8.6 \pm 0.3 \mathrm{~mm}$ and $9.6 \pm 0.6 \mathrm{~mm}$ respectively).

The growth of some gram positive bacteria was also inhibited by the $C$. oliveri leaf extracts (Figure 3). The growth of 2 of the 4 gram positive bacteria species screened ( $50 \%$ ) was inhibited by the C. oliveri leaf extracts. However, in general, only the methanolic and aqueous C. oliveri leaf extracts inhibited the growth of the gram positive bacteria. Furthermore, the inhibition of gram positive bacterial growth appeared substantially less potent than was the inhibition of gram negative growth (as deter- 
Table 3: $\mathrm{LC}_{50}$ (95\% confidence interval) for Artemia nauplii exposed to the C. oliveri leaf extracts and the reference toxin potassium dichromate.

\begin{tabular}{|c|c|c|}
\hline \multirow[t]{2}{*}{ Extract } & \multicolumn{2}{|c|}{$\mathrm{LC}_{50}(\mu \mathrm{g} / \mathrm{mL})$} \\
\hline & $24 \mathrm{~h}$ & $48 h$ \\
\hline Methanol & $1487 \pm 127$ & $783 \pm 22$ \\
\hline Water & $1626 \pm 185$ & $1136 \pm 125$ \\
\hline Ethyl acetate & $\mathrm{CND}$ & CND \\
\hline Chloroform & $\mathrm{CND}$ & CND \\
\hline Hexane & $\mathrm{CND}$ & $\mathrm{CND}$ \\
\hline Potassium dichromate & $88 \pm 5$ & $82 \pm 4$ \\
\hline
\end{tabular}

Results represent the mean \pm SEM of triplicate determinations. CND indicates that a $\mathrm{LC}_{50}$ could not be determined as the mortality did not exceed $50 \%$ at any concentration tested.

mined by zone of inhibition.

The antimicrobial efficacy was further quantified by determining the MIC values for each extract against the microbial species which were determined to be susceptible. The methanolic, aqueous and ethyl acetate C. oliveri leaf extracts were potent growth inhibitors of several bacterial species (as judged by MIC; Table 2). P. mirabilis was the most susceptible bacteria to the $C$. oliveri leaf extracts, with MIC values as low as 127 $\mu \mathrm{g} / \mathrm{mL}$ for the methanolic extract (approximately $1 \mu \mathrm{g}$ infused into the disc) recorded for against this bacteria. The MIC values determined for the aqueous and ethyl acetate extract against $P$. mirabilis also indicate potent growth inhibition (525 and $688 \mu \mathrm{g} / \mathrm{mL}$ respectively). As $P$. mirabilis infection is a common cause of urinary tract infections and has also been identified as a trigger of rheumatoid arthritis, ${ }^{22,23}$ the aqueous and methanolic $C$. oliveri extracts have potential for the prevention aqnd treatment of these diseases in genetically susceptible individuals. Furthermore, the aqueous, methanolic and ethyl acetate $C$. oliveri leaf extracts were also potent $E$. coli and K. pneumomiae growth inhibitors, with MIC values generally in the $200-700 \mu \mathrm{g} / \mathrm{mL}$ range. As $K$. pneumoniae can trigger ankylosing spondylitis in genetically susceptible individuals, ${ }^{24,25}$ these extracts may also be useful in the prevention and treatment of this disease. The aqueous and methanolic C. oliveri leaf extracts were also good B. cereus growth inhibitors (MIC $<700 \mu \mathrm{g} / \mathrm{mL}$ ). Moderate to low growth inhibition (or no inhibition) was noted for all other extract/bacterium combinations.

\section{Bacterial growth time course assay}

The antibacterial activity of the C. oliveri extracts was further investigated in the most susceptible bacterial species (E. coli, K. pneumoniae, P. mirabilis) by bacterial growth time course assays in the presence and absence of the extract. Only the effect of the methanolic extract on the bacterial growth time courses was evaluated as this extract was generally more potent than the other $C$. oliveri extracts. The starting concentration of the extract used in these assays was $1000 \mu \mathrm{g} / \mathrm{mL}$. The methanolic $C$. oliveri extract significantly inhibited E. coli (Figure 4a), K. pneumoniae (Figure $4 \mathrm{~b}$ ) and $P$. mirabilis (Figure $4 \mathrm{c}$ ) growth within $1 \mathrm{~h}$, indicating a rapid antimicrobial action. Whilst both E. coli and K. pneumoniae growth was inhibited for at least the first 4 hours of the time course, the bacteria were generally able to overcome this inhibition by $6 \mathrm{~h}$, with the recorded turbidity not significantly different to that of the untreated control. This indicates that the growth inhibition of these bacteria was bacteriostatic for the methanolic $C$. oliveri extract at the concentrations tested against these bacteria. In contrast, inhibition of $P$. mirabilis by the methanolic C. oliveri extract was substantially more profound, with growth still significantly inhibited by the end of the $6 \mathrm{~h}$ time course study. Indeed, the turbidity in the presence of the methanolic extract at $6 \mathrm{~h}$ was not greatly increased from the starting turbidity. In contrast, the aqueous extract did not completely inhibit $P$. mirabilis growth and levels approaching those seen in the untreated control were evident by $6 \mathrm{~h}$. This may indicate that the aqueous extract is bacteriostatic, whilst the methanolic C. oliveri has bactericidal activity against $P$. mirabilis at the dose tested.

\section{Quantification of toxicity}

The toxicity of the C. oliveri extracts was initially tested in the Artemia franciscana nauplii bioassay at a concentration of $2000 \mu \mathrm{g} / \mathrm{mL}$ (Figure 5). The aqueous and methanolic extracts induced $>50 \%$ mortality at $24 \mathrm{~h}$ and were thus deemed to be toxic. All other extracts induced low levels of mortality at $24 \mathrm{~h}$, similar to the \% mortality seen for the seawater control. By $48 \mathrm{~h}$, the aqueous and methanolic extracts had induced approximately $100 \%$ mortality. Whilst mortality induction by the ethyl acetate and chloroform extracts was significantly higher than that in the untreated control following $48 \mathrm{~h}$ exposure, the levels were still $<50 \%$ and thus were deemed to be nontoxic. In contrast, the potassium dichromate positive control induced mortality within $4 \mathrm{~h}$ (results not shown), with $100 \%$ mortality induction seen by $24 \mathrm{~h}$.

To further quantify the effect of toxin concentration on the induction of mortality, the extracts were serially diluted in artificial seawater to test across a range of concentrations in the Artemia nauplii bioassay (Table 3). For comparison, serial dilutions of potassium dichromate were also tested. All extracts were determined to be nontoxic, with $\mathrm{LC}_{50}$ values substantially greater than $1000 \mu \mathrm{g} / \mathrm{mL}$ following $24 \mathrm{~h}$ exposure. Extracts with an $\mathrm{LC}_{50}$ of greater than $1000 \mu \mathrm{g} / \mathrm{mL}$ towards Artemia nauplii have previously been defined as being nontoxic. ${ }^{21}$

\section{DISCUSSION}

Plant derived remedies are becoming increasingly sought after in the treatment of a myriad of diseases and disorders due both to their perception of greater safety than synthetic drugs, and the failure of current drug regimens to effectively treat many diseases. Our study reports on the growth inhibitory properties of $C$. oliveri leaf extracts against a panel of pathogenic bacteria, and on their toxicity. The gram positive and gram negative bacteria tested in this study demonstrated similar susceptibilities towards the C. oliveri leaf extracts. In contrast, many previous studies with other plant species report a greater susceptibility of many bacterial species towards solvent extracts for South American, ${ }^{26}$ African ${ }^{27}$ and Australian plant extracts. ${ }^{28,29}$

Our study examined the ability of $C$. oliveri leaf extracts to inhibit the growth of a panel of medicinally important bacterial pathogens. The methanolic and aqueous extracts were identified as being particularly potent inhibitors of $P$. mirabilis with MIC values of 127 and $525 \mu \mathrm{g} / \mathrm{mL}$ respectively. The ethyl acetate extract and chloroform extracts were also good $P$. mirabilis growth inhibitors, albeit with higher MIC values (688, 987 and $1066 \mu \mathrm{g} / \mathrm{mL}$ respectively). As $P$. mirabilis can trigger rheumatoid 
arthritis in genetically susceptible individuals, ${ }^{22,23}$ these extracts have potential for the development of rheumatoid arthritis inhibitory therapies. The methanolic and aqueous extract also displayed potent K. pneumoniae growth inhibitory properties, with MIC values 686 and $706 \mu \mathrm{g} / \mathrm{mL}$ respectively. The ethyl acetate, chloroform and hexane extracts were also moderate-good $K$. pneumoniae growth inhibitors with MIC values $<1500 \mu \mathrm{g} / \mathrm{mL}$. As $K$. pneumoniae can trigger ankylosing spondylitis in genetically susceptible individuals, ${ }^{30,31}$ this extract may also be useful in the prevention and treatment of ankylosing spondylitis. Whilst not as potent, the methanolic and aqueous C. oliveri extracts were moderate inhibitors of S. pyogenes growth (MICs of 1680 and 2263 $\mu \mathrm{g} / \mathrm{mL}$ respectively). C. oliveri leaf extracts also inhibited the growth of several bacterial species associated with food poisoning. The methanolic, aqueous and ethyl acetate extracts were particularly potent inhibitors of growth of E. coli growth, with MIC values of 215, 427 and $330 \mu \mathrm{g} / \mathrm{mL}$ respectively. The chloroform and hexane extracts were also moderate $E$. coli growth inhibitors, albeit with higher MIC values $(1255$ and $1438 \mu \mathrm{g} /$ $\mathrm{mL}$ respectively). Similarly, the methanolic and aqueous $C$. oliveri leaf extracts were potent inhibitors of B. cereus growth (MIC $<1000 \mu \mathrm{g} / \mathrm{mL}$ ), and the ethyl acetate extract was a moderate growth inhibitor (MIC $=1500 \mu \mathrm{g} / \mathrm{mL}$ ). Therefore, the $C$. oliveri leaf extracts have therapeutic potential in the treatment of food poisoning, diarrhoea and dysentery.

Whilst a detailed investigation of the phytochemistry of the C. oliveri leaf extracts was beyond the scope of our study, qualitative screening studies were used to determine the classes of compounds present. Some commonalities were noted: the most potent aqueous and methanolic extracts all contained relatively high levels of total phenolics and flavonoids. It is likely that these and other phytochemical classes may contribute to the growth inhibitory properties of these extracts. Our qualitative phytochemical screening studies also indicated that triterpenoids, phytosterols and saponins were present in the C. oliveri leaf extracts. Many studies have reported potent antibacterial activities for a wide variety of these compounds. ${ }^{8}$ Further phytochemical evaluation studies and bioactivity driven isolation of active components is required to further evaluate the mechanism of bacterial growth inhibition.

The findings reported here also demonstrate that all of the C. oliveri leaf extracts were nontoxic towards Artemia franciscana nauplii, with $\mathrm{LC}_{50}$ values substantially $>1000 \mu \mathrm{g} / \mathrm{mL}$. Extracts with $\mathrm{LC}_{50}$ values $>1000 \mu \mathrm{g} /$ $\mathrm{mL}$ towards Artemia nauplii are defined as being nontoxic. ${ }^{21}$ Whilst our preliminary toxicity studies indicate that these extracts may be safe for therapeutic use, studies using human cell lines are required to further evaluate the safety of these extracts. Furthermore, whilst these studies have demonstrated the potential of the $C$. oliveri leaf extracts in the development of future antibiotic chemotherapeutics for the prevention and treatment of urinary tract infections, autoimmune diseases (particularly rheumatoid arthritis and ankylosing spondylitis), more work is required to isolate the inhibitory components and determine the mechanism of inhibition.

\section{CONCLUSIONS}

The results of this study demonstrate the potential of the C. oliveri leaf extracts as inhibitors of pathogenic bacteria growth. Furthermore, their lack of toxicity indicates than they are safe for internal as well as topical treatment. Further studies aimed at the purification and identification of bioactive components are required to examine the mechanisms of action of these agents.

\section{ACKNOWLEDGEMENTS}

The authors are grateful to Philip Cameron for providing the C. oliveri leaves used in this study, and to Michelle Mendell and Jane Gifkins for the gift of the clinical isolate bacterial strains. Financial support for this work was provided by the Environmental Futures Research Institute and the School of Natural Sciences, Griffith University, Australia.

\section{CONFLICTS OF INTEREST}

The authors report no conflicts of interest.

\section{ABBREVIATIONS}

DMSO: Dimethyl sulfoxide; $\mathrm{LC}_{50}$ : The concentration required to achieve $50 \%$ mortality; MIC: minimum inhibitory concentration.

\section{REFERENCES}

1. Cowan MM. Plant products as antimicrobial agents. Clinical microbiology reviews. 1999;12(4):564-82. PMid:10515903 PMCid:PMC88925.

2. Bhavnani SM, Ballow $\mathrm{CH}$. New agents for Gram-positive bacteria. Current Opinion in Microbiology. 2000;3(5):528-34. https://doi.org/10.1016/S13695274(00)00134-X.

3. Chariandy CM, Seaforth CE, Phelps RH, Pollard GV, Khambay BP. Screening of medicinal plants from Trinidad and Tobago for antimicrobial and insecticidal properties. Journal of Ethnopharmacology. 1999;64(3):265-70. https://doi. org/10.1016/S0378-8741(98)00130-5.

4. Patwardhan B, Warude D, Pushpangadan $P$, Bhatt N. Ayurveda and traditional Chinese medicine: a comparative overview. Evidence-based Complimentary and Alternative Medicine 2005;2:465-473. https://doi.org/10.1093/ecam/ neh140; PMid:16322803 PMCid:PMC1297513.

5. Hostettmann K, Marston A, Ndjoko K, Wolfender JL. The potential of African plants as a source of drugs. Current Organic Chemistry. 2000;4(10):973-1010. https://doi.org/10.2174/1385272003375923.

6. Paz EA, Cerdeiras MP, Fernandez J, Ferreira F, Moyna P, Soubes M, Vazquez A, Vero S, Zunino L. Screening of Uruguayan medicinal plants for antimicrobial activity. Journal of Ethnopharmacology. 1995;45(1):67-70. https://doi. org/10.1016/0378-8741(94)01192-3

7. Cock IE. Medicinal and aromatic plants - Australia. In Ethnopharmacology, Encyclopedia of Life Support Systems (EOLSS), 2011. Developed under the auspices of UNESCO. Oxford, UK: EOLSS Publishers; 2011. Available from: http:// www.eolss.net. Accessed 1 April 2013.

8. Cock IE. The phytochemistry and chemotherapeutic potential of Tasmannia lanceolata (Tasmanian pepper): A review. Pharmacognosy Communications. 2013:3(4):13-25. DOI: 10.5530/pc.2013.4.4.

9. Arkhipov A, Sirdaarta J, Rayan P, McDonnell PA, Cock IE. An examination of the antibacterial, antifungal, anti-Giardial and anticancer properties of Kigelia africana fruit extracts. Pharmacognosy Communications. 2014 Jul:4(3):62-76. https://doi.org/10.5530/pc.2014.3.7.

10. Kalt FR, Cock IE. Gas chromatography-mass spectroscopy analysis of bioactive Petalostigma extracts: Toxicity, antibacterial and antiviral activities. Pharmacognosy Magazine. 2014;10(37):S37-49. https://doi.org/10.4103/0973-1296.127338; PMid:24914307 PMCid:PMC4047571

11. Vesoul J, Cock IE. The potential of Bunya nut extracts as antibacterial functional food agents. Pharmacognosy Communications. 2012;2(1):72-9. https:// doi.org/10.5530/pc.2012.1.13.

12. Courtney R, Sirdaarta J, Matthews B, Cock IE. Tannin components and inhibitory activity of Kakadu plum leaf extracts against microbial triggers of autoimmune inflammatory diseases. Pharmacognosy Journal. 2015;7(1):18-31. https:// doi.org/10.5530/pj.2015.7.2.

13. Chikowe G, Mpala L, Cock IE. Antibacterial activity of selected Australian Syzygium species. Pharmacognosy Communications 2013;3(4):77-83. DOI: 10.5530/pc.2013.4.11.

14. Wright MH, Matthews B, Arnold MS, Greene AC, Cock IE. The prevention of fish spoilage by high antioxidant Australian culinary plants: Shewanella putrefaciens growth inhibition. International Journal of Food Science \& Technology 2016 Jan 1. https://doi.org/10.1111/ijfs.13026.

15. Sautron C, Cock IE. Antimicrobial activity and toxicity of Syzygium australe and Syzygium leuhmannii fruit extracts. Pharmacognosy Communications 2014;4(1):53-60. https://doi.org/10.5530/pc.2014.1.8.

16. Hart C, llanko P, Sirdaarta J, Rayan P, McDonnell PA, Cock IE. Tasmannia stipitata as a functional food/natural preservative: Antimicrobial activity and toxicity. Pharmacognosy Communications. 2014;4(4):33-47. DOI: 10.5530/pc.2014.4.4.

17. Cock IE. Antimicrobial activity of Acacia aulacocarpa and Acacia complanta methanolic extracts. Pharmacognosy Communications 2012;2(1): 66-71. https:// doi.org/10.5530/pc.2012.1.12.

18. Bryant K, Cock IE. Eupomatia laurina R. Br. fruit solvent extractions inhibit the growth of a panel of pathogenic bacteria. Pharmacognosy Communications. 2017;7(1):16-23. DOI: 10.5530/pc. 2017.1.3

19. Cock IE, Ruebhart DR. Assessment of the toxicity of selected Australian native plant extracts using the Artemia franciscana nauplii bioassay. The Internet Jour- 
nal of Toxicology. 2008;5(2):2.

20. Ruebhart DR, Wickramasinghe W, Cock IE. Protective efficacy of the antioxidants vitamin E and Trolox against Microcystis aeruginosa and microcystin-LR in Artemia franciscana nauplii. Journal of Toxicology and Environmental Health, Part A. 2009;72(24):1567-75. https://doi.org/10.1080/15287390903232459; PMid:20077231.

21. Cock IE, Ruebhart DR. Comparison of the brine shrimp nauplii bioassay and the ToxScreen-Il test for the detection of toxicity associated with Aloe vera (Aloe barbadensis Miller) leaf extract. Pharmacognosy Research 2009;1(2): 98-101.

22. Cock IE, van Vuuren SF. Anti-Proteus activity of some South African medicinal plants: their potential for the prevention of rheumatoid arthritis. Inflammopharmacology. 2014;22(1):23-36. https://doi.org/10.1007/s10787-013-0179-3; PMid:23877712

23. Ebringer A, Rashid T. Rheumatoid arthritis is an autoimmune disease triggered by Proteus urinary tract infection. Journal of Immunology Research. 2006;13(1):41-8

24. Cock IE, van Vuuren SF. The potential of selected South African plants with antiKlebsiella activity for the treatment and prevention of ankylosing spondylitis. Inflammopharmacology. 2015;23(1):21-35. https://doi.org/10.1007/s10787-014 0222-z; PMid:25412961.

25. Ebringer $A$, Rashid T, Wilson $C$, et al. Ankylosing spondylitis as an auto-immune disease linked to intestinal Klebsiella infection: prospects for a new therapeutic approach. Current Rheumatology Reviews 2006;2:55-68. https://doi.org/10.217

\section{4/157339706775697044.}

26. Mohanty S, Cock IE. Evaluation of the antibacterial activity and toxicity of Myrciaria caulifloria methanolic leaf and fruit extracts. Internet J Microbiol. 2009;7(2)

27. Cock IE, van Vuuren SF. South African food and medicinal plant extracts as potential antimicrobial food agents. Journal of Food Science and Technology. 2015;52(11):6879-99. https://doi.org/10.1007/s13197-015-1806-3.

28. Cock IE, Kukkonen L. An examination of the medicinal potential of Scaevola spinescens: Toxicity, antibacterial, and antiviral activities. Pharmacognosy Research. 2011;3(2):85. https://doi.org/10.4103/0974-8490.81955; PMid:21772751 PMCid:PMC3129029

29. Vesoul J, Cock IE. An examination of the medicinal potential of Pittosporum phylliraeoides: toxicity, antibacterial and antifungal Activities. Pharmacognosy Communications. 2011;1(2):8-17. https://doi.org/10.5530/pc.2011.2.3.

30. Cock IE, van Vuuren SF. The potential of selected South African plants with antiKlebsiella activity for the treatment and prevention of ankylosing spondylitis. Inflammopharmacology. 2015;23(1):21-35. https://doi.org/10.1007/s10787-014 0222-z; PMid:25412961.

31. Rashid T, Ebringer A. Ankylosing spondylitis is linked to Klebsiella - the evidence. Clinical rheumatology. 2007;26(6):858-64. https://doi.org/10.1007/ s10067-006-0488-7; PMid:17186116

\section{PICTORIAL ABSTRACT}

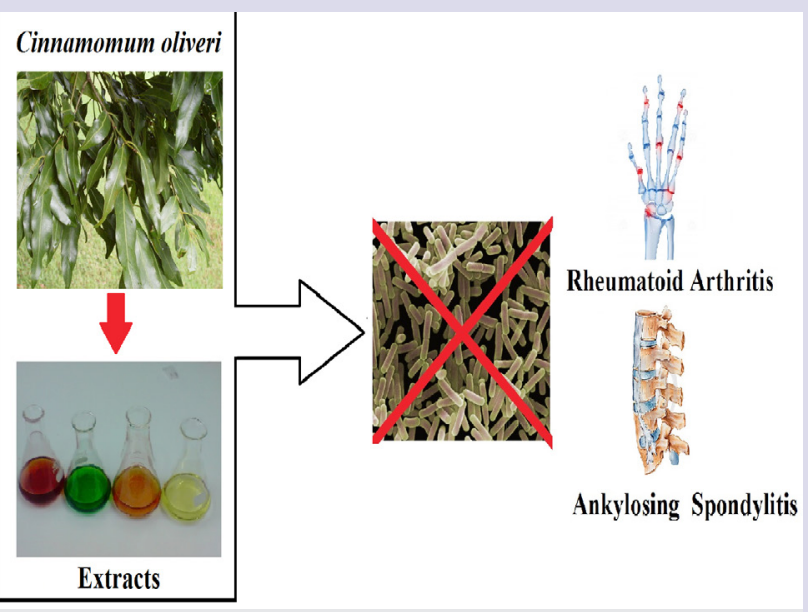

\section{SUMMARY}

- C. oliveri leaf extracts displayed broad spectrum antibacterial activity against gram positive and gram negative bacteria.

- Methanolic, aqueous and ethyl acetate extracts were potent inhibitors o P. mirabilis growth (MIC values as low as $127 \mu \mathrm{g} / \mathrm{mL}$ ).

- $\quad$ E. coli, K. pneumoniae and B. cereus were also particularly susceptible (MICs substantially $<1000 \mu \mathrm{g} / \mathrm{mL}$ ).

- $\quad$ All C. oliveri leaf extracts were nontoxic in the Artemia nauplii bioassay.

\section{ABOUT AUTHORS}

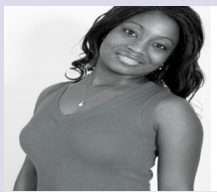

Ms Getmore Chikowe completed at BSc at Griffith University in life sciences. Following graduation, she undertook a research project in Dr lan Cock's laboratory in the School of Natural Sciences at Griffith University. The project examined the growth inhibitory properties of a variety of Australian native plants against an extensive panel of bacterial pathogens.

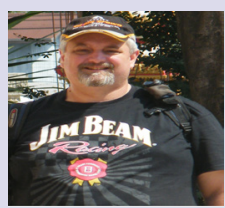

Dr lan Cock leads a research team in the Environmental Futures Research Institute and the School of Natural Sciences at Griffith University, Australia. His research involves bioactivity and phytochemical studies into a variety of plant species of both Australian and international origin, including Aloe vera, South Asian and South American tropical fruits, as well as Australia plants including Scaevola spinescens, Pittosporum phylliraeoides, Terminalia ferdinandiana (Kakadu plum), Australian Acacias, Syzygiums, Petalostigmas and Xanthorrhoea johnsonii (grass trees). This range of projects has resulted in nearly 200 publications in a variety of peer reviewed journals.

Ms Lindiwe Mpala completed at BSc at Griffith University in life sciences. Following graduation, she undertook a research project in Dr lan Cock's laboratory in the School of Natural Sciences at Griffith University. The project examined the growth inhibitory properties of a variety of Australian native plants against an extensive panel of bacterial pathogens. 